\title{
Polychlorinated dibenzo- $p$-dioxin and dibenzofuran concentrations in the serum samples of workers at continuously burning municipal waste incinerators in Japan
}

Shinji Kumagai, Shigeki Koda, Takashi Miyakita, Hideki Yamaguchi, Kenichi Katagi, Nobufumi Yasuda

Department of

Occupational Health, Osaka Prefectural Institute of Public Health, Japan S Kumagai

Department of Public Health, Kochi Medical

School, Japan

S Koda

N Yasuda

Department of Hygiene, Kumamoto University School of Medicine, Japan

T Miyakita

Kumamoto Occupational Safety and Health Center, Japan

H Yamaguchi

Kobe Hospital, Hyogo Medical Cooperation, Japan

K Katagi

Correspondence to: Dr S Kumagai, Department of Occupational Health,

Osaka Prefectural Institute of Public Health, 1-3-69 Nakamichi, Higashinari-ku, Osaka 537, Japan

Accepted 12 November 1999

\begin{abstract}
Objectives-To find whether concentrations of polychlorinated dibenzo- $p$-dioxins (PCDDs) and polychlorinated dibenzofurans (PCDFs) in serum increased in workers at municipal incinerators that burn continuously.

Methods-30 Workers employed at three municipal waste incineration plants (incinerator workers) and 30 control workers were studied. The incinerator workers had worn dust masks or airline masks during the periodic repair work inside the incinerators. Previous job, dietary habit, smoking habit, distance from residence to the incineration plant, and body weight and height were obtained from a questionnaire survey. Concentrations of PCDDs/PCDFs were measured in the serum of the workers and the dust deposited in the plants. The influence of various factors on serum concentrations of PCDDs/PCDFs was examined by multiple regression analysis.
\end{abstract}

Results-Dust analysis showed the greatest amount of octachlorodibenzo- $p$-dioxin (OCDD), followed by $1,2,3,4,6,7,8-$ heptachlorodibenzo- $p$-dioxin (HpCDD), 1,2,3,4,6,7,8-heptachlorodibenzofuran (HpCDF), and octachlorodibenzofuran (OCDF). The toxicity equivalents (TEQs) of PCDDs and PCDFs in the deposited dust were 4.8, 1.0, and $6.4 \mathrm{ng}$ TEQs/g, respectively, for plants $A, B$, and $C$. The mean serum TEQs of PCDDs and PCDFs in the incinerator workers and control workers were 19.2 and $22.9 \mathrm{pg}$ TEQs/g lipid, respectively, for area $A, 28.8$ and 24.5 pg TEQs/g lipid for area B, and 23.4 and $23.6 \mathrm{pg}$ TEQs/g lipid for area C. No significant differences were found between the incinerator workers and the controls for TEQs of PCDDs and PCDFs separately, and TEQs of PCDDs and PCDFs together. However, the serum 1,2,3,4,6,7,8-HpCDF concentration was significantly higher in the incinerator workers than in the controls for all the three areas. When the exposure index to $1,2,3,4,6,7,8-\mathrm{HpCDF}$ is defined as the product of the concentration of $1,2,3,4,6,7,8-\mathrm{HpCDF}$ in the deposited dust and duration of employment, the concentration of $1,2,3,4,6,7,8-\mathrm{HpCDF}$ in serum increased as the exposure index increased. Multivariate analysis suggested that the serum concentration of $\mathrm{HpCDF}$ increased with duration of employment at the incineration plants and OCDF increased with employment of $\geqslant 21$ years. The other significant variables $(p<0.01$ or $\mathbf{p}<0.001$ ) were area for hexachlorodibenzo-p-dioxin (HxCDD) and tetrachlorodibenzofuran (TCDF), Brinkman index for HpCDD, and body mass index (BMI) for tetrachlorodibenzo- $p$-dioxin (TCDD), HpCDD, and TEQs of PCDDs.

Conclusion-The serum TEQs of PCDDs and PCDFs was not significantly higher among the incinerator workers, but the serum concentration of $1,2,3,4,6,7,8-$ HpCDF was. This suggests that the incinerator workers had inhaled dust containing PCDDs and PCDFs while working in plants equipped with incinerators that burn continuously.

(Occup Environ Med 2000;57:204-210)

Keywords: serum dioxins; municipal waste incinerators; continuous burning; heptachlorodibenzofuran

Polychlorinated dibenzo- $p$-dioxins (PCDDs) and polychlorinated dibenzofurans (PCDFs) are chemically and biologically similar compounds and also highly toxic chemicals. They already contaminate the environment including: air, water, and soil, and foods such as fish, meat, and vegetables. ${ }^{1-3}$ The PCDDs and PCDFs are also found in human adipose tissue, blood, and milk. ${ }^{14-6}$ Main sources of PCDDs and PCDFs are production of organic chlorinated herbicides, bleaching of paper or pulp, and incineration of waste. ${ }^{7-9}$ In Japan, incinerators are the most important source ${ }^{10}$ because most solid waste is incinerated in municipal waste incinerators without sufficient measures to prevent the generation of these chemicals. Concentrations of PCDDs and PCDFs in the exhaust gas of 1150 municipal waste incinerators ranged from $<0.01$ to $990 \mathrm{ng}$ toxicity equivalents (TEQs)/ $\mathrm{Nm}^{3}\left(\mathrm{~m}^{3}\right.$ at $0^{\circ} \mathrm{C}$ and 1 atmosphere $)$ in 1996-97. ${ }^{11}$ The municipal incinerators were classified into intermittent burning and day and night continuous burning types, and concentrations of PCDDs and PCDFs in the exhaust gas was generally higher in the intermittent than in the continuous burning types. In Toyono, Osaka prefecture, a municipal waste incineration plant equipped with 
Table 1 Characteristics of incinerator workers and control workers at the three areas

\begin{tabular}{|c|c|c|c|c|c|c|}
\hline & \multicolumn{2}{|l|}{$A$} & \multicolumn{2}{|l|}{$B$} & \multicolumn{2}{|l|}{$C$} \\
\hline & Incinerator workers & Controls & Incinerator workers & Controls & Incinerator workers & Controls \\
\hline Workers (n) & 10 & 10 & 10 & 10 & 10 & 10 \\
\hline Age $(y$, mean $(S D))$ & $50.4(5.4)$ & $52.5(4.0)$ & $47.8(4.4)$ & $48.2(5.5)$ & $45.4(3.4)$ & $43.9(4.2)$ \\
\hline $\begin{array}{l}\text { Employment duration at incineration plant (y, } \\
\text { mean (SD)) }\end{array}$ & $22.0(5.9)$ & 0 & $23.6(3.3)$ & 0 & $24.5(3.0)$ & 0 \\
\hline $\begin{array}{l}\text { Fish } \\
\text { Meat } \\
\text { Milk }\end{array}$ & $\begin{array}{l}6.7(3.4) \\
6.6(3.0)^{\star} \\
6.3(4.8)\end{array}$ & $\begin{array}{l}6.7(2.9) \\
3.9(1.8) \\
3.0(2.2)\end{array}$ & $\begin{array}{l}7.4(3.4) \\
6.1(3.8) \\
4.3(4.1)\end{array}$ & $\begin{array}{l}9.3(3.5) \\
6.5(3.0) \\
5.6(4.4)\end{array}$ & $\begin{array}{l}7.2(3.6) \\
7.5(4.1) \\
6.1(4.9)\end{array}$ & $\begin{array}{l}6.8(3.6) \\
6.5(1.4) \\
2.7(2.9)\end{array}$ \\
\hline Current smoking habit: & & & & & & \\
\hline Non-smokers (workers, $\mathrm{n}$ ) & 6 & 4 & 7 & 4 & 5 & 7 \\
\hline Smokers (workers, $\mathrm{n}$ ) & 4 & 6 & 3 & 6 & 5 & 3 \\
\hline Brinkman index (cigarettes/day $\times y$, mean (SD)) & $1038(242)$ & $895(405)$ & $700(520)$ & $570(140)$ & $690(320)$ & $730(429)$ \\
\hline Distance from municipal incinaration plant to resi & ence (workers, $n$ ): & & & & & \\
\hline$<5 \mathrm{~km}$ & 3 & 4 & 2 & 2 & 9 & 10 \\
\hline$\geqslant 5 \mathrm{~km}$ & 7 & 6 & 8 & 8 & 1 & 0 \\
\hline Body mass index $\left(\mathrm{kg} / \mathrm{m}^{2}\right.$, mean (SD)) & $23.5(3.3)$ & $23.2(2.9)$ & $23.3(3.4)$ & $25.5(2.3)$ & $22.7(3.0)$ & $25.6(3.7)$ \\
\hline
\end{tabular}

intermittently burning incinerators scattered a large amount of high concentrations of fume and dust containing PCDDs and PCDFs due to defective equipment, and the soil of the ground outside was contaminated at $0.1-$ $52000 \mathrm{ng}$ TEQs/g. ${ }^{12}$ The surrounding agricultural land was also contaminated at up to 8.5 ng TEQs/g. The Ministry of Labor conducted a medical examination of the workers employed at the incineration plant, and found that the mean concentration of PCDDs and PCDFs in blood was 323 pg TEQs/g lipid among the highly exposed worker group. ${ }^{13}$ This value was about 15 times as high as that of the general population. The finding raised the question as to whether workers employed at incineration plants equipped with continuously burning incinerators were exposed to PCDDs and PCDFs of a similar level. In this study, serum concentrations of PCDDs and PCDFs were measured for workers employed at three municipal waste incineration plants with continuously burning incinerators. The influence of some factors, including diet and smoking, on serum concentrations of PCDDs and PCDFs was also examined. This study was approved by the Osaka Prefectural Institute of Public Health.

\section{Subjects and methods} SUBJECTS

Three municipal waste incineration plants A, $\mathrm{B}$, and $\mathrm{C}$ equipped with continuously burning incinerators were selected in Fukuoka, Kochi, and Osaka prefectures, Japan, respectively. Three incinerators were operated in plants A and $\mathrm{B}$, and four in plant $\mathrm{C}$. The incinerators of plants $\mathrm{A}$ and $\mathrm{B}$ were equipped with electrostatic precipitators for removing particulate matter from the flue gas stream. In plant C, three incinerators were equipped with electrostatic precipitators and one with a bag filter. The incinerated volumes were 160,300 , and 600 tonnes/day at plants A, B, and C, respectively. In 1996-97, concentrations of PCDDs and PCDFs in the exhaust gas of the incinerators with electrostatic precipitators were 8.9-42, 0.82-1.4 and 3.1-12 ng TEQs/ $\mathrm{Nm}^{3}$, respectively, whereas that of the incinera- tor with a bag filter was $0.07-0.24 \mathrm{ng}$ TEQs $/ \mathrm{Nm}^{3}$.

Numbers of workers employed at plants A, $\mathrm{B}$, and $\mathrm{C}$ were 32,60 , and 147 , respectively, and 28,38 , and 74 of the workers were employed in the operation and repair of the incinerator. From these incinerator workers in each plant, 10 men were selected by the duration of employment, and they participated after a full explanation of the study. These workers usually operated and inspected the incinerators, and periodically did repair work inside the incinerators and electrostatic precipitators (every 1-3 months). The repair work was performed wearing a dust mask or airline mask. For comparison, 10 male workers matched for age ( 5 years) were selected from the municipal governmental employees in areas A and C, and from members of a labor union for area $B$. They were clerical workers in areas A and C, and six clerical workers, two drivers, a cook, and a medical doctor in area $\mathrm{B}$. The control workers were not occupationally exposed to PCDDs and PCDFs. The age ranged from 40 to 59 years among the incinerator workers and from 38 to 59 years among the controls. The means of age and duration of employment at the incineration plants are shown in table 1 .

QUESTIONNAIRE SURVEY

The workers were questioned on the previous job, numbers of meals of fish, meat, and cow's milk in a week, smoking habit, distance (linear $\mathrm{km}$ ) from residence to the incineration plant, and body weight and height, because these variables could have confounding effects.

QUANTITATIVE DETERMINATION OF PCDDS AND PCDFS

Reagents

Standard solutions of PCDDs and PCDFs were purchased from Wellington Laboratories (Canada). Silica gel and aluminium oxide for cleaning up were obtained from Merck (Germany). Other reagents were obtained from Wako Pure Chemical Industries (Japan).

\section{Serum}

The workers were asked not to eat breakfast, and a blood sample (about $100 \mathrm{ml}$ ) was 


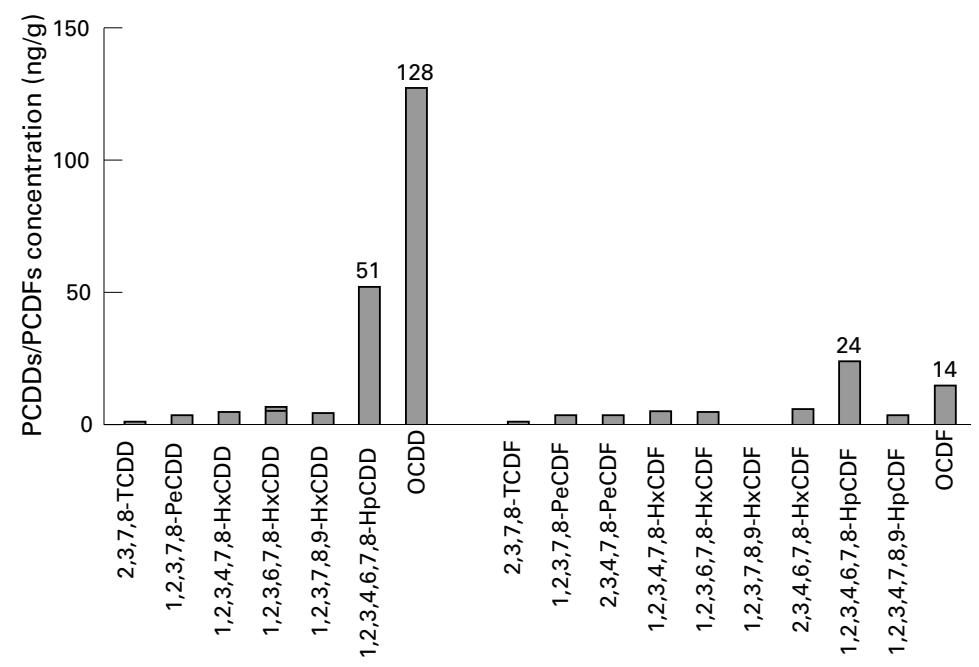

Figure 1 Isomer pattern of deposited dust in incineration plant $C$.

collected from each in the morning in 1998. The serum was separated by centrifugation and collected in a chemically clean container. After addition of ${ }^{13} \mathrm{C}_{12}-2,3,7,8$-substituted PCDDs and PCDFs as internal standards, the sample was kept frozen at $-30^{\circ} \mathrm{C}$ until the time of analysis.

A $40 \mathrm{ml}$ serum sample was extracted twice with $27 \mathrm{ml}$ aqueous saturated ammonium sulphate, $27 \mathrm{ml}$ ethanol, and $80 \mathrm{ml}$ hexane. ${ }^{14}$ The hexane extract was washed with deionised water and dried, and the lipid was measured gravimetrically. Next, the lipid was decomposed in $10 \mathrm{ml} 1 \mathrm{~N} \mathrm{KOH} /$ ethanol solution for 2 hours at room temperature, and PCDDs and PCDFs were extracted twice with $25 \mathrm{ml}$ hexane. ${ }^{15}$ The hexane extract was cleaned with a multistage column of silica gel coated with $\mathrm{AgNO}_{3}, \mathrm{H}_{2} \mathrm{SO}_{4}$, and $\mathrm{KOH}$, and an aluminium oxide column. ${ }^{15}$ The effluent was dried and reconstituted to $10 \mu \mathrm{l}$ with nonane containing ${ }^{13} \mathrm{C}_{12}-1,2,3,4$ tetrachlorodibenzo- $p$-dioxin (TCDD). Finally, 2,3,7,8-substituted PCDDs and PCDFs were measured with a high resolution gas chromatograph (HP5890II, Hewlett Packard, USA)/ high resolution mass spectrometry (JMS700,

Table 2 PCDDs and PCDFs (pg/g lipid) in the serum of incinerator workers and controls in city $A$

\begin{tabular}{|c|c|c|c|c|c|c|}
\hline & \multicolumn{3}{|c|}{ Incinerator workers $(n=10)$} & \multicolumn{3}{|c|}{ Controls $(n=10)$} \\
\hline & Mean & Median & (Range) & Mean & Median & (Range) \\
\hline 2,3,7,8-TCDD & 2.4 & 2.6 & $(1.1-3.8)$ & 2.2 & 2.3 & (ND-3.8) \\
\hline 1,2,3,7,8-PeCDD & 9.0 & 8.6 & $(5.8-12.9)$ & 12.7 & 10.5 & $(6.0-33.9)$ \\
\hline $1,2,3,4,7,8-\mathrm{HxCDD}$ & 3.0 & 3.1 & $(\mathrm{ND}-6.1)$ & 2.7 & 2.6 & (ND-6.5) \\
\hline $1,2,3,6,7,8-\mathrm{HxCDD}$ & 23.6 & 19.4 & $(12.3-40.1)$ & 28.7 & 30.5 & $(10.8-51.0)$ \\
\hline $1,2,3,7,8,9-\mathrm{HxCDD}$ & 4.8 & 4.5 & $(2.7-7.1)$ & 4.9 & 5.5 & (ND-9.8) \\
\hline $1,2,3,4,6,7,8-\mathrm{HpCDD}$ & 23.8 & 19.7 & $(9.4-57.0)$ & 17.3 & 17.8 & $(6.7-39.4)$ \\
\hline OCDD & 260 & 166 & $(95.2-670)$ & 247 & 248 & $(73.0-503)$ \\
\hline $2,3,7,8-\mathrm{TCDF}$ & 2.7 & 2.9 & $(1.7-3.7)$ & 2.4 & 1.9 & $(\mathrm{ND}-7.7)$ \\
\hline $1,2,3,7,8-\mathrm{PeCDF}$ & 2.0 & $1.9^{\star}$ & $(1.3-3.2)$ & 1.1 & 0.5 & (ND-3.0) \\
\hline $2,3,4,7,8-\mathrm{PeCDF}$ & 12.9 & 12.3 & $(5.1-18.9)$ & 16.4 & 14.0 & $(9.5-30.0)$ \\
\hline $1,2,3,4,7,8-\mathrm{HxCDF}$ & 5.6 & 5.7 & $(1.5-11.6)$ & 8.1 & 8.0 & $(4.2-12.2)$ \\
\hline $1,2,3,6,7,8-\mathrm{HxCDF}$ & 6.1 & 5.7 & $(2.3-10.8)$ & 6.4 & 6.2 & $(3.5-10.7)$ \\
\hline $1,2,3,7,8,9-\mathrm{HxCDF}$ & 1.0 & 0.5 & (ND-3.3) & 0.5 & 0.5 & (ND-ND) \\
\hline $2,3,4,6,7,8-\mathrm{HxCDF}$ & 3.7 & 3.7 & (ND-6.2) & 2.5 & 2.4 & (ND-4.2) \\
\hline $1,2,3,4,6,7,8-\mathrm{HpCDF}$ & 15.5 & $13.7^{\star \star}$ & $(7.7-28.4)$ & 7.4 & 6.6 & $(4.0-15.7)$ \\
\hline $1,2,3,4,7,8,9-\mathrm{HpCDF}$ & 0.8 & 0.5 & (ND-1.4) & 0.6 & 0.5 & (ND-1.3) \\
\hline OCDF & 2.4 & 2.2 & $(1.2-4.4)$ & 2.0 & 2.1 & (ND-3.0) \\
\hline TEQ-PCDD & 10.5 & 10.6 & $(6.6-14.4)$ & 12.6 & 10.9 & $(5.5-24.5)$ \\
\hline TEQ-PCDF & 8.6 & 8.4 & $(3.8-12.6)$ & 10.3 & 9.1 & $(6.4-17.8)$ \\
\hline TEQ-PCDD/PCDF & 19.2 & 18.1 & $(11.0-26.4)$ & 22.9 & 19.9 & $(12.1-37.8)$ \\
\hline
\end{tabular}

${ }^{\star} \mathrm{p}<0.05 ;{ }^{\star \star} \mathrm{p}<0.01$, by Mann-Whitney $U$ test.
JEOL, Japan) connected to capillary columns of SP2331 $(0.25 \mathrm{~mm}$ internal diameter $\times 60 \mathrm{~m}$, Supelco, USA) for TCDD, pentachlorodibenzo-p-dioxin (PeCDD), hexachlorodibenzo- $p$-dioxin (HxCDD), tetrachlorodibenzofuran (TCDF), pentachlorodibenzofuran (PeCDF), hexachlorodibenzofuran $(\mathrm{HxCDF})$, and of DB5-MS $(0.25 \mathrm{~mm}$ internal diameter $\times 30 \mathrm{~m}, \mathrm{~J}$ and $\mathrm{W}, \mathrm{USA}$ ) for heptachlorodibenzo- $p$-dioxin (HpCDD), octachlorodi benzo- $p$-dioxin (OCDD), heptachlorodibenzofuran (HpCDF), and octachlorodibenzofuran (OCDF). The limit of measurement was $1 \mathrm{pg} / \mathrm{g}$ lipid. Half of the limit value was assigned as an undetectable value. International TEQs were calculated according to the North Atlantic Treaty Organisation (NATO) ${ }^{16}$

For quality assurance, nine $40 \mathrm{ml}$ samples were prepared from our pooled serum samples. To three samples, 2,3,7,8-substituted-PCDDs and PCDFs (0.4 pg for TCDD and TCDF, 80 $\mathrm{pg}$ for OCDD, $4 \mathrm{pg}$ for OCDF, $2 \mathrm{pg}$ for other PCDDs and PCDFs) was added, and to another three samples, twice that amount was added. The remaining three samples were analysed without addition of PCDDs and PCDFs. The coefficient of variation for the lipid measurement was $0.01 \quad(n=9)$. The mean recoveries of ${ }^{13} \mathrm{C}_{12}$-internal standards were $73 \%$ to $83 \%$ with coefficients of variation of 0.09 to 0.14 . The mean biases of the measured value of added PCDDs and PCDFs from the expected value ((measured value-expected value)/ expected value) were -0.11 to 0.11 with coefficients of variation of 0.01 to 0.12 .

\section{Dust}

Samples were taken in the dust deposited on beams at heights of $0.5-1.5 \mathrm{~m}$ in the incineration plants. Fine particles are potentially inhalable, because they can be easily scattered by disturbance and remain suspended in air for a long time, whereas coarse particles cannot. The dust sample was passed through a sieve of $32 \mu \mathrm{m}$, and the concentrations of PCDDs and PCDFs were measured as follows. The sample was first treated with $2 \mathrm{~N} \mathrm{HCl}$ for better extraction efficiency, and the solid content was separated by a filter, washed with deionised water, and then dried at room temperature. The PCDDs and PCDFs in the liquid passing through the filter were extracted twice with toluene, and those in the solid were Soxhletextracted for 16 hours with toluene. The two toluene extracts were combined and washed with deionised water, and the internal standard was added. Procedures of cleaning up and quantitative measurement were almost the same as in the analysis of serum samples.

STATISTICAL ANALYSIS

Differences of serum concentrations of PCDDs and PCDFs between the incinerator workers and controls were examined by MannWhitney $U$ test, because many non-detectable samples were found for some PCDDs and PCDFs. The correlation between exposure index of 2,3,4,6,7,8-HpCDF and log of serum concentration of the $\mathrm{HpCDF}$ was examined by the Pearson correlation coefficient test. 
Table 3 PCDDs and PCDFs (pg/g lipid) in the serum of incinerator workers and controls in city $B$

\begin{tabular}{|c|c|c|c|c|c|c|}
\hline & \multicolumn{3}{|c|}{ Incinerator workers $(n=10)$} & \multicolumn{3}{|c|}{ Controls $(n=10)$} \\
\hline & Mean & Median & (Range) & Mean & Median & (Range) \\
\hline 2,3,7,8-TCDD & 2.5 & 2.4 & $(1.5-5.1)$ & 2.0 & 1.7 & $(1.2-3.7)$ \\
\hline $1,2,3,7,8-\mathrm{PeCDD}$ & 13.4 & 12.9 & $(7.6-31.8)$ & 10.8 & 9.3 & $(8.2-19.9)$ \\
\hline $1,2,3,4,7,8-\mathrm{HxCDD}$ & 5.1 & 4.1 & $(2.4-13.3)$ & 4.2 & 3.7 & $(2.8-9.8)$ \\
\hline $1,2,3,6,7,8-\mathrm{HxCDD}$ & 61.8 & 58.7 & $(37.2-104)$ & 53.3 & 47.2 & $(33.0-78.3)$ \\
\hline $1,2,3,7,8,9-\mathrm{HxCDD}$ & 11.5 & 13.0 & $(4.6-20.2)$ & 9.0 & 7.2 & $(6.1-22.6)$ \\
\hline $1,2,3,4,6,7,8-\mathrm{HpCDD}$ & 41.1 & 27.1 & $(17.8-112)$ & 42.5 & 26.3 & $(22.9-153)$ \\
\hline OCDD & 521 & 436 & $(142-1616)$ & 646 & 505 & $(120-2719)$ \\
\hline $2,3,7,8-\mathrm{TCDF}$ & 1.2 & 1.1 & $(\mathrm{ND}-2.3)$ & 1.3 & 1.0 & (ND-2.8) \\
\hline $1,2,3,7,8-\mathrm{PeCDF}$ & 1.0 & 1.1 & (ND-1.8) & 1.2 & 1.3 & (ND-3.1) \\
\hline $2,3,4,7,8-\mathrm{PeCDF}$ & 17.7 & 15.1 & $(10.5-28.2)$ & 15.5 & 13.2 & $(10.7-34.0)$ \\
\hline $1,2,3,4,7,8-\mathrm{HxCDF}$ & 5.9 & 5.3 & $(2.7-10.1)$ & 5.1 & 4.4 & $(4.0-10.2)$ \\
\hline $1,2,3,6,7,8-\mathrm{HxCDF}$ & 6.5 & 6.2 & $(4.2-9.7)$ & 6.0 & 4.9 & $(4.3-13.8)$ \\
\hline $1,2,3,7,8,9-\mathrm{HxCDF}$ & 0.5 & 0.5 & (ND-ND) & 0.5 & 0.5 & (ND-ND) \\
\hline $2,3,4,6,7,8-\mathrm{HxCDF}$ & 3.8 & 3.6 & (ND-8.1) & 2.9 & 2.8 & $(1.4-7.2)$ \\
\hline $1,2,3,4,6,7,8-\mathrm{HpCDF}$ & 9.2 & $8.3^{\star \star}$ & $(5.4-15.3)$ & 5.5 & 4.4 & $(3.3-11.4)$ \\
\hline $1,2,3,4,7,8,9-\mathrm{HpCDF}$ & 0.6 & 0.5 & (ND-1.3) & 0.5 & 0.5 & (ND-ND) \\
\hline OCDF & 1.8 & $1.8^{\star}$ & $(1.2-3.0)$ & 1.2 & 1.2 & (ND-3.0) \\
\hline TEQ-PCDD & 18.0 & 17.7 & $(10.3-36.7)$ & 15.1 & 14.2 & $(10.4-28.0)$ \\
\hline TEQ-PCDF & 10.8 & 9.4 & $(6.7-17.4)$ & 9.5 & 8.2 & $(6.5-20.7)$ \\
\hline TEQ-PCDD/PCDF & 28.8 & 27.4 & $(17.0-54.1)$ & 24.5 & 22.8 & $(17.5-48.7)$ \\
\hline
\end{tabular}

${ }^{\star} \mathrm{p}<0.05 ;{ }^{\star \star} \mathrm{p}<0.01$, by Mann-Whitney $U$ test.

Table 4 PCDDs and PCDFs (pg/g lipid) in the serum of incinerator workers and controls in city $C$

\begin{tabular}{|c|c|c|c|c|c|c|}
\hline & \multicolumn{3}{|c|}{ Incinerator workers $(n=10)$} & \multicolumn{3}{|c|}{ Controls $(n=10)$} \\
\hline & Mean & Median & (Range) & Mean & Median & (Range) \\
\hline 2,3,7,8-TCDD & 1.9 & 2.1 & $(1.1-2.4)$ & 2.0 & 1.9 & $(\mathrm{ND}-4.1)$ \\
\hline $1,2,3,7,8-\mathrm{PeCDD}$ & 9.7 & 9.4 & $(6.1-13.4)$ & 9.9 & 10.4 & $(5.9-14.5)$ \\
\hline $1,2,3,4,7,8-\mathrm{HxCDD}$ & 3.4 & 3.0 & (ND-7.2) & 4.3 & 3.8 & (ND-12.6) \\
\hline $1,2,3,6,7,8-\mathrm{HxCDD}$ & 48.2 & 41.7 & $(27.1-81.9)$ & 55.0 & 56.8 & $(29.6-77.4)$ \\
\hline $1,2,3,7,8,9-\mathrm{HxCDD}$ & 7.6 & 6.9 & $(3.8-16.5)$ & 9.4 & 10.4 & (ND-24.3) \\
\hline $1,2,3,4,6,7,8-\mathrm{HpCDD}$ & 29.2 & 24.7 & $(12.5-72.5)$ & 48.1 & 26.4 & $(12.1-234)$ \\
\hline OCDD & 499 & 186 & $(119-2048)$ & 565 & 228 & $(102-3061)$ \\
\hline $2,3,7,8-\mathrm{TCDF}$ & 1.0 & 1.1 & (ND-1.8) & 1.5 & 1.2 & $(\mathrm{ND}-3.5)$ \\
\hline $1,2,3,7,8-\mathrm{PeCDF}$ & 1.5 & 1.4 & (ND-2.9) & 1.2 & 1.1 & $(\mathrm{ND}-2.2)$ \\
\hline $2,3,4,7,8-\mathrm{PeCDF}$ & 15.0 & 16.1 & $(7.5-23.0)$ & 14.1 & 14.1 & $(6.4-20.7)$ \\
\hline $1,2,3,4,7,8-\mathrm{HxCDF}$ & 5.7 & 5.6 & $(2.8-9.1)$ & 4.5 & 4.6 & (ND-8.5) \\
\hline $1,2,3,6,7,8-\mathrm{HxCDF}$ & 8.2 & 7.0 & $(5.7-13.1)$ & 6.2 & 6.1 & $(3.1-9.5)$ \\
\hline $1,2,3,7,8,9-\mathrm{HxCDF}$ & 0.9 & 0.5 & (ND-2.3) & 0.5 & 0.5 & (ND-ND) \\
\hline $2,3,4,6,7,8-\mathrm{HxCDF}$ & 5.8 & $5.6^{\star}$ & $(2.0-9.7)$ & 2.7 & 2.4 & $(\mathrm{ND}-5.7)$ \\
\hline $1,2,3,4,6,7,8-\mathrm{HpCDF}$ & 18.9 & $16.7^{\star \star \star}$ & $(6.6-41.3)$ & 5.7 & 5.7 & $(3.1-8.8)$ \\
\hline $1,2,3,4,7,8,9-\mathrm{HpCDF}$ & 0.6 & 0.5 & (ND-1.1) & 0.5 & 0.5 & (ND-ND) \\
\hline OCDF & 2.3 & $2.3^{\star}$ & (ND-4.2) & 1.3 & 1.2 & (ND-2.8) \\
\hline TEQ-PCDD & 13.5 & 13.0 & $(8.2-20.9)$ & 14.9 & 14.4 & $(7.3-28.2)$ \\
\hline TEQ-PCDF & 9.9 & 10.4 & $(5.3-14.5)$ & 8.7 & 8.8 & $(4.0-12.8)$ \\
\hline TEQ-PCDD/PCDF & 23.4 & 22.5 & $(13.5-33.0)$ & 23.6 & 22.9 & $(11.3-40.0)$ \\
\hline
\end{tabular}

${ }^{\star} \mathrm{p}<0.05 ;{ }^{\star \star \star} \mathrm{p}<0.001$, by Mann-Whitney $U$ test.

For HxCDD, PeCDF, HxCDF, and $\mathrm{HpCDF}$ the numbers of the non-detectable samples decreased by summing 2,3,7,8substrated isomers, so that these values were used in the following analyses. The relations between logarithms of serum concentrations of PCDDs and PCDFs and the nine factors of area, age, duration of employment at the incineration plants, numbers of meals of fish, meat, and cow's milk (times/week), Brinkman index $($ smoker $=$ cigarettes/day $\times$ year, non-smoker $=0$ ), distance between incineration plant and residence, and body mass index (BMI) were tested, firstly in a unviariate model and subsequently in a multiple linear regression model. In the univariate analyses, analysis of variance (ANOVA) was used to analyse differences between the three areas (A, B, and C) and three durations of employment $(0,11-20$, and 21-29 years), and $t$ test was performed to test the difference between two groups classified by the other factors. To reduce the number of variables in the multivariate model, only those prognostic factors that were related to the serum concentrations of PCDDs and PCDFs in the univariate analysis $(\mathrm{p}<0.10)$ were included in the model. In the multivariate analyses, two dummy variables, $\mathrm{B} / \mathrm{A}$ (area $\mathrm{B}=1$, other areas $=0$ ) and $\mathrm{C} / \mathrm{A}$ (area $\mathrm{C}=1$, other areas $=0$ ) were used for area, and two dummy variables, 11-20 years as controls (11-20 years $=1$, others $=0$ ) and 21 -29 years as controls (21-29 years $=1$, others $=0)$ for duration of employment. Age, BMI, and Brinkman index were used as continuous values. Data analyses were performed with the SPSS system (9.0J for Windows).

\section{Results}

The TEQ values of PCDDs and PCDFs in the deposited dust were 4.8, 1.0, and $6.4 \mathrm{ng}$ TEQs/g, respectively, for incineration plants A, $\mathrm{B}$, and C. Figure 1 shows the isomer pattern of 2,3,7,8-substituted PCDDs and PCDFs in the deposited dust for plant C: OCDD was dominant, and 1,2,3,4,6,7,8-HpCDD, 1,2,3, $4,6,7,8-\mathrm{HpCDF}$, and OCDF followed. The same isomer pattern was found for plants $\mathrm{A}$ and $\mathrm{B}$.

Table 1 shows the previous job with potential for exposure to PCDDs and PCDFs, dietary, current smoking habit, distance from residence to the incineration plant, and BMI for the incinerator workers and controls. Three in the incinerator workers and one in the controls engaged in agriculture $\geqslant 26$ years ago. Because some herbicides contained PCDDs and PCDFs as impurities, ${ }^{7}$ they might have been exposed to these chemicals. However, they did not remember the name of the herbicides used, so that it was not clear whether they had been exposed to PCDDs and PCDFs in the previous job. The number of meals of meat was the only factor that was significantly different between the two groups in area $\mathrm{A}$.

Tables 2, 3, and 4 shows the concentrations of PCDDs and PCDFs in the serum. The numbers of non-detectable cases were $3,7,3$, $19,22,1,56,7,52$, and 8 for 2,3,7,8-TCDD, 1,2,3,4,7,8-HxCDD, 1,2,3,7,8,9-HxCDD, 2, 3,7,8-TCDF, $1,2,3,7,8$-PeCDF, $1,2,3,4,7,8-$ $\mathrm{HxCDF}, \quad 1,2,3,7,8,9-\mathrm{HxCDF}, 2,3,4,6,7,8-$ $\mathrm{HxCDF}, 1,2,3,4,7,8,9-\mathrm{HpCDF}$, and $\mathrm{OCDF}$, respectively.

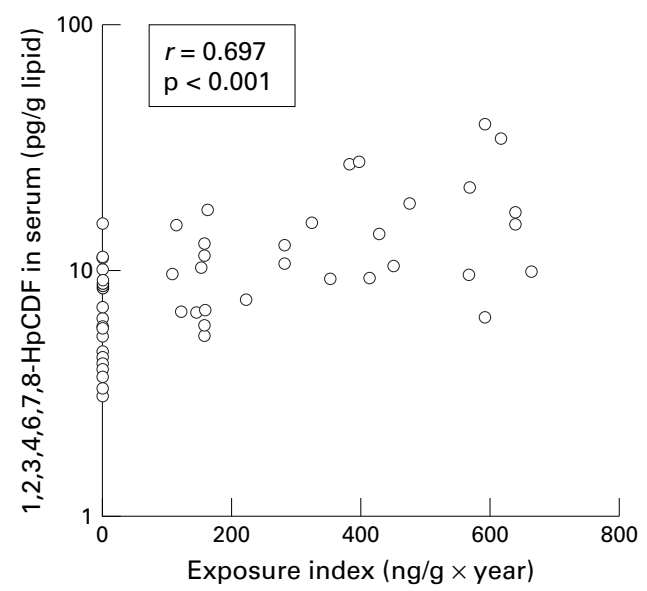

Figure 2 Relation between exposure index and serum concentration of $1,2,3,4,6,7,8-H p C D F$. Exposure index $=$ concentration of $1,2,3,4,6,7,8-H p C D F$ in deposited dust $\times$ duration of employment. 
Table 5 Significance of nine variables by univariate analyses ( $p$ value)

\begin{tabular}{|c|c|c|c|c|c|c|c|c|c|}
\hline & Area & Age & $\begin{array}{l}\text { Employment } \\
\text { duration }\end{array}$ & Fish & Meat & Milk & $\begin{array}{l}\text { Brinkman } \\
\text { index }\end{array}$ & Residence & $B M I$ \\
\hline TCDD & 0.445 & $0.002^{\star \star}$ & 0.332 & 0.387 & 0.382 & 0.522 & 0.901 & 0.269 & 0.274 \\
\hline PeCDD & 0.265 & $0.031^{\star}$ & 0.810 & 0.714 & 0.422 & 0.989 & 0.943 & 0.356 & 0.400 \\
\hline $\mathrm{HxCDD}$ & $0.000^{\star \star \star}$ & $0.056 \dagger$ & 0.766 & 0.876 & 0.622 & 0.721 & 0.745 & 0.989 & 0.567 \\
\hline HpCDD & $0.004^{\star \star}$ & $0.645^{\circ}$ & 0.691 & 0.810 & 0.642 & 0.798 & $0.018^{\star}$ & 0.852 & 0.561 \\
\hline OCDD & $0.055+$ & 0.937 & 0.712 & 0.793 & 0.858 & 0.649 & 0.717 & 0.764 & 0.346 \\
\hline TCDF & $0.004^{\star \star}$ & $0.003^{\star \star}$ & 0.781 & 0.491 & 0.886 & 0.567 & 0.329 & 0.106 & 0.987 \\
\hline PeCDF & 0.546 & $0.034 \dagger$ & 0.607 & 0.445 & 0.560 & 0.797 & 0.792 & 0.161 & 0.390 \\
\hline $\mathrm{HxCDF}$ & 0.772 & $0.111^{\circ}$ & $0.098 \dagger$ & 0.856 & 0.967 & 0.526 & 0.670 & 0.551 & 0.250 \\
\hline $\mathrm{HpCDF}$ & $0.068 \dagger$ & 0.869 & $0.000^{\star \star \star \star}$ & 0.398 & 0.266 & 0.283 & 0.715 & 0.275 & $0.086 \dagger$ \\
\hline OCDF & $0.077 \dagger$ & 0.220 & $0.003^{\star \star}$ & 0.754 & 0.194 & 0.666 & 0.414 & 0.439 & $0.323^{\circ}$ \\
\hline TEQ-PCDD & $0.007^{\star \star}$ & 0.639 & 0.679 & 0.868 & 0.711 & 0.828 & 0.983 & 0.761 & 0.270 \\
\hline TEQ-PCDF & 0.692 & $0.036^{\star}$ & 0.531 & 0.595 & 0.540 & 0.800 & 0.902 & 0.324 & 0.585 \\
\hline TEQ-PCDD/PCDF & $0.077 \dagger$ & 0.211 & 0.570 & 0.756 & 0.593 & 0.808 & 0.897 & 0.566 & 0.346 \\
\hline
\end{tabular}

Area A, B, and C; age 38-47 y $(\mathrm{n}=32)$ and 48-59 $(\mathrm{n}=28)$; employment duration 0 y $(\mathrm{n}=30), 11-20(\mathrm{n}=9)$, and 21-29 ( $\mathrm{n}=21)$; fish, meat, and milk $<7$ times/week $(n=27,39,43)$ and $\geqslant 7(n=33,21,17)$; Breckman index $<400(n=28)$ and $\geqslant 400(n=32)$; residence $<5 \mathrm{~km}(\mathrm{n}=30)$ and $\geqslant 5(\mathrm{n}=30) ; B M I<24 \mathrm{~kg} / \mathrm{m}^{2}(\mathrm{n}=30)$ and $\geqslant 24(\mathrm{n}=30)$.

ANOVA was used for area and employment duration, and $t$ test for the other variables. $+\mathrm{p}<0.10 ;{ }^{\star} \mathrm{p}<0.05 ;{ }^{\star \star} \mathrm{p}<0.01 ;{ }^{\star \star \star} \mathrm{p}<0.001$.

Table 6 Multiple correlation coefficients $(R)$ and estimated standerdised slopes $(\beta)$ by multiple regression analysis

\begin{tabular}{|c|c|c|c|c|c|c|c|c|}
\hline & \multirow[b]{3}{*}{$\begin{array}{l}\text { Adjusted } \\
R^{2}\end{array}$} & \multicolumn{7}{|c|}{ Standardised slope $(\beta)$} \\
\hline & & \multicolumn{2}{|l|}{ Area } & \multicolumn{2}{|c|}{ Employment duration at plant } & \multirow[b]{2}{*}{ Age } & \multirow[b]{2}{*}{$\begin{array}{l}\text { Brinkman } \\
\text { index }\end{array}$} & \multirow[b]{2}{*}{$B M I$} \\
\hline & & $B / A$ & $C / A$ & $\begin{array}{l}11-20 y / \\
\text { control }\end{array}$ & $\begin{array}{l}21-29 y / \\
\text { control }\end{array}$ & & & \\
\hline TCDD & 0.169 & -0.016 & -0.096 & 0.188 & $0.269^{\star}$ & 0.222 & -0.080 & $0.419^{\star \star}$ \\
\hline PeCDD & 0.040 & 0.210 & 0.070 & 0.031 & 0.029 & 0.247 & -0.070 & 0.245 \\
\hline $\mathrm{HxCDD}$ & 0.427 & $0.652^{\star \star \star}$ & $0.522^{\star \star}$ & -0.014 & 0.027 & -0.069 & -0.063 & 0.210 \\
\hline HpCDD & 0.385 & $0.332^{\star}$ & $0.306^{\star}$ & 0.067 & 0.065 & 0.182 & $-0.468^{\star \star \star}$ & $0.375^{\star \star}$ \\
\hline OCDD & 0.103 & 0.274 & 0.104 & -0.018 & 0.025 & 0.041 & -0.135 & $0.343^{\star}$ \\
\hline TCDF & 0.105 & $-0.435^{\star \star}$ & $-0.431^{\star}$ & 0.058 & 0.122 & 0.072 & -0.108 & 0.120 \\
\hline PeCDF & 0.012 & 0.144 & 0.063 & 0.038 & 0.121 & 0.208 & -0.044 & 0.251 \\
\hline $\mathrm{HxCDF}$ & 0.016 & -0.031 & 0.125 & 0.067 & 0.252 & 0.266 & -0.015 & -0.013 \\
\hline $\mathrm{HpCDF}$ & 0.462 & $-0.322^{\star}$ & -0.023 & $0.420^{\star \star \star}$ & $0.624^{\star \star \star}$ & 0.070 & -0.089 & -0.029 \\
\hline $\mathrm{OCDF}$ & 0.214 & $-0.341^{\star}$ & -0.182 & 0.143 & $0.434^{\star \star}$ & 0.147 & -0.134 & 0.018 \\
\hline TEQ-PCDD & 0.189 & $0.400^{\star}$ & 0.267 & 0.029 & 0.080 & 0.104 & -0.114 & $0.351^{\star \star}$ \\
\hline TEQ-PCDF & -0.002 & 0.138 & 0.096 & 0.044 & 0.135 & 0.234 & -0.016 & 0.208 \\
\hline TEQ-PCDD/PCDF & 0.109 & 0.317 & 0.212 & 0.030 & 0.109 & 0.171 & -0.076 & $0.317^{\star}$ \\
\hline
\end{tabular}

$\mathrm{B} / \mathrm{A}(\mathrm{B}=1$, others=0), $\mathrm{C} / \mathrm{A}(\mathrm{C}=1$, others=0), 11-20 years/control $(11-20$ years=1, others=0) and 21-29 years/control $(21-29$ years $=1$, others $=0$ ) are dummy variables.

${ }^{\star} \mathrm{p}<0.05 ;{ }^{\star \star} \mathrm{p}<0.01 ;{ }^{\star \star \star} \mathrm{p}<0.001$.

The means of TEQs of PCDDs and PCDFs in the incinerator workers and controls were 19.2 and $22.9 \mathrm{pg}$ TEQs/g lipid for area A, 28.8 and $24.5 \mathrm{pg}$ TEQs/g lipid for area B, and 23.4 and $23.6 \mathrm{pg}$ TEQs/g lipid for area C. No significant differences in the TEQs of PCDDs and PCDFs separately or together were found between the incinerator workers and the controls. In the four workers who were previously employed in agriculture, serum TEQs of PCDDs and PCDFs were 22.1, 24.5, 26.1, and $54.1 \mathrm{pg}$ TEQs/g lipid. The first three were mean concentrations and the last was the highest value among all the workers. However, it was not clear whether the highest value was due to the previous job.

In area $\mathrm{A}, 1,2,3,7,8-\mathrm{PeCDF}$ and $1,2,3,4,6$, $7,8-\mathrm{HpCDF}$ were significantly higher among the incinerator workers than the controls. In area $\mathrm{B}, 1,2,3,4,6,7,8-\mathrm{HpCDF}$ and OCDF were higher among the incinerator workers. In area $\mathrm{C}, 2,3,4,6,7,8-\mathrm{HxCDF}, 1,2,3,4,6,7,8-$ $\mathrm{HpCDF}$, and OCDF were higher among the incinerator workers. Thus, 1,2,3,4,6,7,8-Hp$\mathrm{CDF}$ was significantly higher among the incinerator workers than the controls in all three areas. When the exposure index to $1,2,3,4$, $6,7,8-\mathrm{HpCDF}$ was defined as the product of concentration of $1,2,3,4,6,7,8-\mathrm{HpCDF}$ in the deposited dust (A $15 \mathrm{ng} / \mathrm{g}, \mathrm{B} 6.1 \mathrm{ng} / \mathrm{g}$, C 24 $\mathrm{ng} / \mathrm{g}$ ) and duration of employment, the
$1,2,3,4,6,7,8-\mathrm{HpCDF}$ concentration in serum increased as the exposure index increased (fig 2).

In the univariate analysis, five variables, area, age, duration of employment, Breckman index, and BMI, were selected for the following multivariate analysis (table 5). Table 6 shows the multiple correlation (R) and standardised slope $(\beta)$ estimated by the multiple linear regression analysis. The $\beta$ value is not interpretable in the units of the variable, but a standardised unit. The multivariate analysis suggested that serum concentration of $\mathrm{HpCDF}$ increased with duration of employment at the incineration plants and OCDF increased with employment of $\geqslant 21$ years. The other significant variables $(p<0.01$ or $\mathrm{p}<0.001$ ) were area for HxCDD and TCDF, Brinkman index for HpCDD, and BMI for TCDD, HpCDD, and TEQs of PCDDs.

\section{Discussion}

Mean blood concentrations of PCDDs and PCDFs in the general population have been reported to be 14 to $43 \mathrm{pg}$ TEQs/g lipid for Europe, ${ }^{5}$ 17-24 19 to $27 \mathrm{pg}$ TEQs/g lipid for North America, ${ }^{25-28}$ and 20 to 22 pg TEQs/g lipid for Japan. ${ }^{29} 30$ In this study, the mean serum concentrations of PCDDs and PCDFs in the incinerator workers and controls were 19 
to $29 \mathrm{pg}$ TEQs/g lipid, which are almost the same as in the industrialised countries.

The incinerators studied were continuously burning type, which generate smaller amounts of PCDDs and PCDFs than the intermittently burning type. The highest concentration of PCDDs and PCDFs in exhaust gas was 8.9-42 $\mathrm{ng} \mathrm{TEQ} / \mathrm{Nm}^{3}$ of plant $\mathrm{A}$. The value was equivalent to the median concentration from municipal waste incinerators in Japan. ${ }^{11}$ Consequently, it should be noted that our findings may not be applicable to other incineration plants with much higher concentrations of PCDDs and PCDFs.

Work at the incineration plant was classified into the usual operation of the incinerator and the periodic repair work inside the equipment, incinerator, and electrostatic precipitator. In the repair work, because a large amount of ash and slag was scattered in air due to sweeping of ash and slag, the workers might be exposed to PCDDs and PCDFs at extremely high concentrations. However, the workers have worn dust masks or airline masks while working inside the equipment since at least 1988, so that the respiratory intake of PCDDs and PCDFs might be suppressed. In the general population, the dietary intake of PCDDs and PCDFs predominates over other routes and differs greatly between people. ${ }^{31}{ }^{32}$ Consequently, a low respiratory intake would not lead to a detectable increase in the serum TEQs of PCDDs and PCDFs. This can explain our findings that the serum concentration of TEQs of PCDDs and PCDFs in the incinerator workers was not higher than in the controls.

However, the incinerator workers probably inhale some ash and slag during the repair work due to leaks in their respiratory protection, because they complained of nostril pollution after the repair work. During normal operation of the incinerator, the workers did not wear any respiratory protection, and thus inhaled the suspended dust in the plants. When the hand and skin of the workers were contaminated with the deposited dust, hand to mouth ingestion and dermal absorption of PCDDs and PCDFs could occur. Comparison of 2,3,7,8substituted concentrations of PCDDs and PCDFs in the deposited dust showed that OCDD was the highest, followed by 1,2,3,4,6,7,8-HpCDD, 1,2,3,4,6,7,8-HpCDF, and OCDF. In general, a similar pattern was also found in fly ash and slag. ${ }^{33}$ In the controls, the variability between workers in serum concentrations of $1,2,3,4,6,7,8-\mathrm{Hp}$ $\mathrm{CDF}$ and $\mathrm{OCDF}$ were much lower than those of OCDD and $1,2,3,4,6,7,8-\mathrm{HpCDD}$ (tables 2,3 , and 4 ), the increases in the dibenzofurans would be easiest to detect when the workers inhaled fly ash, slag, or dust. This agrees with our findings that serum $1,2,3,4,6,7,8-\mathrm{HpCDD}$ and OCDF were significantly higher among the incinerator workers in three and two areas, respectively. Schecter et $a l^{17}$ reported that the increase of the serum HpCDF concentration was most marked at an old incineration plant, which agreed with our result. Consequently, we concluded that the increase in the HpCDF was caused by inhalation of ash, slag, and dust dur- ing work. This conclusion was confirmed by multiple regression analysis that suggested that serum concentrations of $\mathrm{HpCDF}$ increased with duration of employment after the effects of the confounding factors were eliminated.

The positive association between BMI and serum TEQs of PCDDs and PCDFs is consistent with previous reports. ${ }^{25} 34$ This analysis showed that the area was a factor affecting serum concentrations of HxCDD and TCDF. As the importance of area is not known in Japan, further study is necessary. The negative correlation between the Brinkman index and the serum concentration of HpCDD was unexpected as tobacco smoke contains PCDDs and PCDFs. ${ }^{35}$ Passive smoking might be important as a factor because all cigarette smoke, whether smoked by the worker or not, contains PCDDs and PCDFs. In general, fish is more contaminated with PCDDs and PCDFs than other foods - for example, meat and cow's milk. ${ }^{23}$ Because fish consumption is much higher in Japan than in Europe and North America, it is considered to be an important factor. However, our univariate analysis did not find the number of meals of fish to be a significant factor. The concentrations of PCDDs and PCDFs is higher in inshore fish than in pelagic fish and fish imported from uncontaminated countries such as southeast Asia. In this study, only the number of meals of fish was questioned. To clarify the relation between fish consumption and the serum concentrations of PCDDs and PCDFs, more detailed information is necessary. A positive association between age and TEQs of PCDDs and PCDFs is well known, ${ }^{19} 254$ but this analysis did not find an age dependency. The range of ages of the workers was 38-59, which might have been too narrow to investigate a significant relation between age and TEQs of PCDDs and PCDFs.

The four workers previously employed in agriculture $\geqslant 26$ years ago did not remember the name of the used herbicides. Although the concentration of TEQs of PCDDs and PCDFs in one of the workers was the highest among all workers, in the other three workers the values were means. Because the number of the workers was small and it was not clear whether they had been exposed to PCDDs and PCDFs in their previous job, this factor was not included in the analyses.

\section{Conclusion}

The serum TEQs of PCDDs and PCDFs in all of the incinerator workers and controls were almost the same as in other industrialised countries. The comparison between the incinerator workers and controls did not show differences in the serum TEQs of PCDDs and PCDFs, but the concentration of $1,2,3,4,6,7,8-$ $\mathrm{HpCDF}$ was higher among the incinerator workers in all three areas although the workers wore respiratory protection during the repair work. This suggests that the incinerator workers inhaled dust containing PCDDs and PCDFs during their work. Consequently, if incinerator workers perform periodic repair work without respiratory protection, the serum TEQs of PCDDs and PCDFs could be higher. Also, 
when the concentrations of PCDDs and PCDFs in dust rises greatly, the serum TEQs of PCDDs and PCDFs can increase, even if incinerator workers wear the respiratory protection.

This study was supported by the Grant in Aid for Scientific Research from the Ministry of Education, Science, Sports, and Culture. We are grateful for the advice on analysis of PCDDs and PCDFs from the following investigators of the Osaka Prefectural Institute of Public Health: Department of Environmental Sanitation, Chief M Ugawa and I Watanabe; Department of Food Chemistry, Chief S Hori, K Kuwabara, H Obana, Y Konishi, M Okihashi, and M Kitagawa.

1 Schecter A. Dioxins and related chemicals in humans and the environment. In: MGallo, RJ Scheuplein, KA VanderHeijden, eds. Biological basis for risk assessment of dioxins and related compounds. Cold Spring Harbor, NY: Cold Spring Harbor Laboratory, 1991:169-213. (Banbury Report 35.)

2 Furst P, Furst C, Groebel W. Levels of PCDDs and PCDFs in food-stuffs from the Fed

3 Fiedler H, Cooper KR, Bergek S, et al. Polychlorinated dibenzo-p-dioxins and polychlorinated dibenzofurans
(PCDF/PCDD) in food samples collected in southern Mississippi, USA. Chemosphere 1997;34:1411-9.

4 Sielken RL. Statistical evaluation reflecting the skewness in the distribution of TCDD levels in humans adipose tissue. the distribution of TCDD levels
Chemosphere 1987;16:2135-40.

Chemosphere 1987;16:2135-40.
5 Schuhmacher M, Domingo JL, Llobet JM, et al. Dioxin and dibenzofuran concentrations in blood of a general populadibenzofuran concentrations in blood of a general popula-
tion from Tarragona, Spain. Chemosphere 1999;38:1123tion 33 .

6 Vartiainen T, Saarikoski S, Jaakola J, et al. PCDD, PCDF, and PCB concentrations in human milk from two areas in Finland. Chemosphere 1997;34:2571-83.

7 Sweeny MH, Fingerhut MA, Patterson DG, et al. Comparison of serum levels of 2,3,7,8-TCDD in TCP production workers and in an unexposed comparison group. Chemosphere 1990;20:993-1000.

8 Amendola G, Barna D, Blosser R, et al. The occurrence and fate of PCDDs and PCDFs in five bleached kraft pulp and paper mills. Chemosphere 1989;18:1181-9.

9 Tong HY, Karasek FW. Comparison of PCDD and PCDF in flyash collected from municipal incinerators of different in flyash collected from municipal inciner

10 Committee for Dioxin Risk Assessment, Environment Agency, Japan. Risk assessment of dioxin. Tokyo: Chuo Agency, Japan. Risk assessment
Houki, 1997:87-8. (In Japanese.)

11 Ministry of Welfare, Japan. List of PCDD/PCDF concentrations in exhaust gas from incinerators. Tokyo: Ministry of Welfare, 1997. (In Japanese.)

12 Ministry of Welfare, Japan. Report of the committee on dioxins pollution at Toyono incineration plant. Tokyo: Ministry of Welfare, 1998. (In Japanese.)

13 Japan Industrial Safety and Health Association, Japan. Report on dioxin problem at Toyono incineration plant. Tokyo: Japan Industrial Safety and Health Association, 1999. (In Japanese.)

14 Ryan JJ, Mills P. Lipid extraction from blood and biological samples and concentrations of dioxin-like compounds. Chemosphere 1997;34:999-1099.

15 Hori S, Konishi Y, Kuwabara K. Decrease of PCDDs, PCDFs, and Co-PCBs levels in human milk from Osaka (1973-96). Organohalogen Compounds 1999;44:141-5.

16 North Atlantic Treaty Organization. International toxicity equivalency factor (I-TEQ) method for risk assessment for comof dioxins and related compounds. Brussels: NATO, 1988
17 Schecter A, Päpke O, Ball M, et al. Dioxin concentrations in the blood of workers at municipal waste incinerators. Occup Environ Med 1995;52:385-7.

18 Gonzalez CA, Kogevinas M, Huici A, et al. Blood levels of polychlorinated dibenzodioxins, polychlorinated dibenzofurans and polychlorinated biphenyls in the general population of a Spanish mediterranean city. Chemosphere 1998;36:419-26.

19 Jiménez B, Hernández LM, Eljarrat E, et al. Levels of PCDDs, PCDFs and non-ortho PCBs in serum samples on non-exposed individuals living in Madrid (Spain). Chemosphere 1996;33:2403-10.

20 Päpke O, Ball M, Lis A. PCDD/PCDF in humans, a 1993update of background data. Chemosphere 1994;29:235560

21 Deml E, Mangelsdorf I, Greim H. Chlorinated dibenzodioxins and dibenzofurans $(\mathrm{PCDD} / \mathrm{F})$ in blood and human milk of non-occupationally exposed persons living in the vicinity of a municipal waste incinerator. Chemosphere 1996;33:1941-50.

22 Päpke O, Herrmann Th, Ball M. PCDD/PCDFs in humans, follow-up of background data for Germany, 1996. Organohalogen Compounds 1997;33:530-4.

23 Wuthe J, Piechotowoski I, Päpke O, et al. First data on background levels of non-ortho and mono-ortho PCBs in blood of residents from southern Germany. Chemosphere 1996;32: $567-74$

24 Johansen HR, Alexander J, Rossland OJ, et al. PCDDs, PCDFs, and PCBs in human blood in relation to consumption of crabs from a contaminated fjord area in Norway. Environ Health Perspect 1996;104:756-64.

25 Tepper A, Burt S, Piactelli L, et al. Serum levels of polychlorinated dibenzo- $p$-dioxins and dibenzofurans in pulp and paper mill workers. Chemosphere 1997;34:1587-603.

26 Ryan JJ, Dewailly E, Gilman A, et al. Dioxin-like compounds in fishing people from the lower north shore of the St Lawrence River, Quebec, Canada. Arch Environ Health 1997;52:309-16

27 Cole DC, Kearney J, Ryan JJ, et al. Plasma levels and profiles of dioxin and dioxin-like compounds in Ontario Great lakes anglers. Chemosphere 1997;34:1401-9.

28 Schecter A, Päpke O, Fürst P, et al. Temporal changes in dioxin and dibenzofuran levels in general population human blood and milk from Germany and the United States. Organohalogen Compounds 1997;33:473-8.

29 Iida T, Hirakawa H, Matsueda T, et al. Recent trend of polychlorinated dibenzo-p-dioxins and their related compounds in the blood and sebum of Yusho and Yu-Cheng patients. Chemosphere 1999;38:981-93.

30 Matsueda $\mathrm{T}$, Hirakawa $\mathrm{H}$, Iida $\mathrm{T}$, et al. Concentrations of dioxins and related compounds in human blood. 7th Symposium on environmental chemistry program and abstract. Osaka, Japan: Japan Society for Environmental Chemistry 1998:134. (In Japanese.)

31 Beck H, Ekhart K, Wittkowski W. PCDD and PCDF body burden from food intake in the Federal Republic of Germany. Chemosphere 1989;18:417-24.

32 Huisman M, Eerensteun SE, Koopman-Esseboom C, et al. Perinatal exposure to polychlorinated biphenyls and dioxins through dietary intake. Chemosphere 1995;31:427387

33 Chang MB, Chung YT. Dioxin contents fly ashes of MSW incineration in Taiwan. Chemosphere 1998;36:1959-68.

34 Devine OJ, Karon JM, Flanders WD et al. Relationships between concentrations of 2,3,7,8-tetrachlorodibenzo-pdioxin in serum and personal characteristics in US Army Vietanam veterans. Chemosphere 1990;20:681-91.

35 Lofroth G, Zebuhr Y. Polychlorinated dibenzo-p-dioxins and dibenzofurans in mainstream and sidestream cigarette smoke. Bull Environ Contam Toxicol 1992;48:789-94. 